\title{
Los Cumpleaños de SAn SimÓn. ETNOgRafías SALVAdOREÑAS
}

\author{
San Simon Birthdays. Salvadorian Ethnographies
}

\author{
Antonio García-Espada
}

Resumen: Presentamos aquí una serie de trabajos de campo, hechos desde la metodología de la observación participante, sobre fiestas y celebraciones relacionadas con el culto a san Simón en El Salvador entre los años 2011 y 2014. Nos ocuparemos, de la forma más descriptiva posible, de seis casos que mantienen entre sí sustanciales diferencias de forma y fondo y que, en su conjunto, prueban la extraordinaria maleabilidad de este culto, así como la imposibilidad de reducir su existencia y el extraordinario éxito de difusión experimentado en los últimos años a razonamientos simplistas y paternalistas como la pobreza, la ignorancia o la marginalidad.

Palabras clave: san Simón, san Judas, santos apócrifos, religiosidad popular.

Abstract: This paper presents a series of case studies on celebrations of San Simon's birthday in El Salvador from 2011 to 2014. From the participant observation vantage point this study introduces six fieldwork cases very different in form and substance. By showing the extraordinary malleability of the cult, this paper also aims to prove the inadequacy of the prevailing theoretical model, which explains the extraordinary popularity and spread of San Simon's cult throughout the country in simplistic and paternalistic terms such as the result of poverty, ignorance and social exclusion.

Keywords: San Simon, Saint Jude, apocryphal saints, popular religion.

\footnotetext{
Antonio García Espada, doctor en Historia y Civilización por el Instituto Universitario Europeo de Florencia, Italia. Profesor titular de tiempo completo de la Facultad de Ciencias Sociales de la Universidad Autónoma de Chiapas, México. Temas de especialización: orígenes de la modernidad, expansión europea, literatura de viajes, religiosidad popular, estudios subalternos. Correo electrónico: antonio.espada@unach.mx.

Enviado a dictamen: 30 de noviembre de 2015. Aprobación: 1 de marzo de 2016. Revisiones: 1 .
} 


\section{Introducción}

E I santoral de la Iglesia católica señala el 28 de octubre como el día de san Simón y san Judas. En varios lugares de Centroamérica se celebra la ocasión con procesiones, alabanzas, bailes, cohetes y una noche entera de vigilia en torno a la imagen del apóstol. La imagen de Judas, sin embargo, contiene infinidad de variantes iconográficas, particularmente en México y Centroamérica. Se le representa con una gran moneda de oro colgando del cuello, con la llamita pentecostal sobre la cabeza, con la mano derecha extendida hacia el espectador, portando una escuadra en la mano izquierda o con la enorme maza con que fue martirizado según las distintas versiones apócrifas de la vida del apóstol.

Entre las variantes más originales, sin duda, está la que representa al santo sentado, con bigote, vestido con saco y corbata, tocado con sombrero y fumando tabaco. Dicha imagen es la que en Centroamérica recibe el nombre de san Simón, o Monchito en algunos ambientes de El Salvador. A esta peculiar versión de san Judas le gusta el tabaco, el alcohol, la música, la fiesta. Se le atribuyen deseos sexuales, celos y posesividad. Por estas u otras razones, muchas prostitutas, homosexuales y delincuentes lo consideran su santo protector. No obstante, su extraordinario éxito de difusión por el país, y en general por toda la región, ha abierto considerablemente el rango de devotos/clientes hasta incorporar todo tipo de profesiones, ámbitos sociales y procedencias étnicas. Dentro de este mismo proceso evolutivo, la figura de san Simón está cada vez más desvinculada de la de san Judas y, de hecho, en algunos casos funge ya como una deidad completamente independiente, e incluso exterior al propio catolicismo.

A continuación presentamos una serie de trabajos de campo hechos desde la perspectiva del observador participante en varios contextos bien diferenciados a lo largo y ancho de todo El Salvador. Cabe advertir que buena parte de la información obtenida en trabajo de campo no puede ser hecha pública por deseo expreso de los propios informantes, por lo que no ha sido considerada en este texto. La circunspección, el recelo e incluso el secreto juegan un papel preponderante en esta manifestación de religiosidad vernácula que, con mayor o menor precisión, suele ser considerada esotérica (García Espada, 2013 y 2015).

Pero la investigación de los cultos apócrifos en El Salvador supone un desafío metodológico aún mayor y directamente relacionado con el manejo de la oralidad; la oralidad como modalidad no tanto de pensamiento, como de acción (Malinowski, 1995), la oralidad como complejo de perspectivas (Eliade, 1957; Ong, 2002), la oralidad como desafío a la temporalidad (Lotman, 1996), la oralidad como creación de un mundo a medida que va siendo habitado (Sloek, 1996), la oralidad como estado de presubjetividad (León, 2001) o la oralidad como desafío último a la esencia misma de las ciencias sociales (Bowman, 2004). A partir de estas advertencias, nos hemos acercado a nuestras fuentes de información teniendo siempre presentes las dificultades en las condiciones de interacción entre nosotros, los investigadores, y este mundo de oralidad que, además, está fuertemente opacado por el escarnio y el desprecio de los medios de comunicación de masas y otras instancias oficiales de poder. Así, para evitar la "distorsión producida por una concentración demasiado positivista" (Said, 2008: 28), hemos optado por la versión más poliédrica de los hechos y una hermenéutica abierta que no aplica criterios tajantes a la hora de producir distinciones u otros criterios de ordenación (De Muralt, 2008). Aquí es de gran importancia el carácter público y multitudinario de las celebraciones asociadas a este culto que, en El Salvador, son conocidas como los cumpleaños de san Simón. Dichas celebraciones nos permitieron movernos con gran libertad, acceder al testimonio de un buen número de informantes en las mejores condiciones posibles y, a partir de ahí, establecer relaciones más profundas y duraderas que nos han permitido ensayar una mirada, si no del todo desprejuiciada, al menos decidida a lograrlo.

\section{Tamanique}

El templo de San Simón de Tamanique se encuentra en la espectacular cordillera del Bálsamo, a la orilla del río 
Tamanique y a los pies de un magnifico cerro conocido indistintamente como el Cerrón, Cerro El Cenizo o Ciudad Vieja. El templo ocupa unos quinientos metros cuadrados de las dos hectáreas que corresponden a la finca. La construcción es de cemento y el techo de lámina metálica sostenida por pilares de hierro. Está bien mantenida y todo pintado con brillantes azules, rojos y blancos. El interior es diáfano y luminoso, con una altura aproximada de ocho metros en la parte baja y doce en la parte correspondiente al altar. El altar está separado del resto del conjunto por un pequeño coro dentro del que se sitúa una amplia mesa con algunas sillas y, pegada a la pared, la imagen de San Simón flanqueada por dos escalinatas que dan acceso directo al santo. El día de la celebración del cumpleaños todo el interior estaba profusamente decorado con flores, tanto naturales como "hechizas". Los alrededores del templo están salpicados de árboles frutales y pequeños cultivos de caña de azúcar, milpa, flor de Jamaica, albahaca y otras plantas aromáticas y medicinales que, amén de comestibles, proporcionan a la finca un delicioso aroma. El terreno es propiedad del hermano Lito y el templo fue terminado de construir en 1995.

No teniendo cerca núcleo poblacional alguno, la finca por lo general está desocupada, aunque vigilada por un guarda y su familia, que habitan allí de forma permanente. El día de la celebración — trasladada en 2012 al sábado 27 de octubre para aprovechar el asueto dominical y llevar a cabo la vigilia completa- se registró la asistencia de unas cuatrocientas personas llegadas en vehículos propios, en transporte colectivo o en alguno de los tres autobuses fletados por el propio hermano Lito desde Soyapango, populosa ciudad industrial al este de la conurbación capitalina. Entre los presentes encontramos personas de todas las edades, distribuidas equitativamente según género y con una considerable presencia de niños y ancianos. De la treintena de entrevistas realizadas, deducimos una composición de clase social media-baja que, en El Salvador, incluye profesiones liberales como abogados, asalariados como policías, autónomos como vendedores ambulantes y otras profesiones más improvisadas e informales. De nuestros entrevistados, aproximadamente un treinta por ciento cursaba o poseía una licenciatura.

Un grupo de elegidos de no más de cuarenta personas, hombres y mujeres de dieciséis a setenta años, estuvieron a cargo de la mayor parte de las tareas organizativas y asistenciales del evento. El resto de los asistentes se referían a ellos como miembros de la cofradía, aunque a sí mismos preferían denominarse "la directiva". Llevaban tres días en el templo de Tamanique, acondicionando el lugar, y el día del cumpleaños ellos fueron los encargados de preparar los manjares con que fueron agraciados todos los presentes. Tamales de pollo, frijoles, tortillas, arroz, chow mein, atol chuco, fresco de flor de Jamaica y otros refrescos comerciales abundaron durante todo el día y la noche de la vigilia. Pero a los cofrades tocó también amenizar la fiesta con otras mañas, como la quema de fuegos artificiales, la organización de una tómbola, la presentación, elección y coronación de la reina de la fiesta y la interpretación de varios números musicales. Este apartado, el musical, ocupó una porción significativa de la tarde del sábado $\mathrm{y}$, aunque la mayor parte de las interpretaciones fueron hechas por los miembros de la directiva, hubo también espacio para otros proponentes. El primer acto fue llevado a cabo por una pareja de niños de siete y ocho años que, vestidos a la moda, interpretaron un famoso reggaetón. A continuación siguieron varias piezas de música folklórica salvadoreña y centroamericana bailadas por grupos de mujeres vestidas de vivos colores. Solistas masculinos, femeninos e infantiles amenizaron la tarde hasta ya entrada la noche, repitiéndose con cierta frecuencia las actuaciones jocosas, las parodias, las burlas y los disfraces grotescos. Sin duda, el número que despertó el más efusivo reconocimiento del público fue el interpretado por Julito, uno de los hijos adoptivos del hermano Lito. Julito es un fornido y apuesto varón de unos veinticinco años de edad que salió ataviado con una larga peluca rubia, unas ostentosas gafas de sol y un vestido corto acabado en minifalda que dejaba al descubierto los hombros y enmarcaba con un generoso escote dos pechos postizos. Julito bailó con excepcional maestría una cumbia discotequera, llegando en ocasiones a efectuar pasos decididamente 
eróticos. Nada grosero, por supuesto, pero fue objeto de grandes carcajadas y algún que otro aspaviento de rubor fingido por parte del alborotado público.

Todo esto tuvo lugar frente a la fachada principal del templo, en una amplia explanada rodeada de gradas que proporcionaban asiento a casi un tercio de los asistentes. Otro de los números musicales que cabe destacar aquí fue el desarrollado por un grupo de jóvenes de la Iglesia adventista. Los temas interpretados eran alabanzas a Jesús y sus apóstoles dentro del inconfundible estilo que en la región llaman música cristiana. A pesar de que alguno de los músicos —ocho en total-demostró cierta habilidad con el instrumento - particularmente los de cuerda-, no se trataba ni remotamente de profesionales, y de hecho todo el ímpetu estaba puesto en la devoción con que los cánticos iban dirigidos al dios crucificado y su corte palestina. La banda pertenecía a una comunidad pequeña y particularmente pobre de un caserío de Corinto, en las orillas del lago Ilopango. Los músicos formaban parte de la comitiva que acompañaba al líder de la comunidad adventista. Su presencia e intervención musical ante la imagen de san Simón era parte de la muestra de agradecimiento al santo por una curación milagrosa. La ruidosa contradicción que, a nuestros ojos, significa ver a un adventista implorar el socorro de un santo pseudocatólico, no encontró solución satisfactoria en ninguna de las respuestas que recibimos de los músicos de Corinto. Se trataba de un milagro, que aquí claramente adquiría el sentido de "algo inexplicable".

Una vez terminado el carrusel musical, tuvieron lugar la coronación de la reina de la fiesta, el lanzamiento de cohetes - que consumieron más de cien kilos de pólvora- y las artes de una banda de músicos, estos sí, profesionales. Así lo indicaban su porte, sus instrumentos, sus habilidades y su amplio repertorio. Sin embargo, su intervención quedó algo deslucida según fue avanzando la noche y se hicieron más notables los estragos del "guaro" introducido de contrabando en la fiesta por los propios músicos. Entre el resto de los asistentes no alcanzamos a identificar más que pequeñas muestras etílicas en tres o cuatro individuos. La sorpresa en este sentido fue mayúscula. La festividad de san Simón es inseparable del alcohol y la borrachera. Sin embargo, el hermano Lito había prohibido las ofrendas de puro y guaro. El san Simón de Tamanique se ha vuelto abstemio y tampoco quiere ver signo alguno de borrachera entre sus devotos.

Según Lito, el culto a san Simón tiene que evolucionar con los nuevos tiempos. Con nuevos tiempos se refería a un aspecto central de la dura batalla librada por las Iglesias no católicas, evangélicas y pentecostales, contra el alcohol, y que ha pasado a convertirse en una de sus principales señas de identidad y claves de su incontestable éxito. Desde los púlpitos no católicos del país se culpa al alcohol de algunos de los principales problemas del "pueblo": la violencia, la holgazanería, la miseria. El mensaje está calando en la sociedad salvadoreña y la abstinencia ha pasado a formar parte de sus esperanzas en una sociedad mejor; también para los seguidores del hermano Lito.

Al sobrepasar la media noche tuvo comienzo el que bien podemos considerar acto central de la celebración del cumpleaños. El escenario cambió completamente. La mayoría de los asistentes entró en el templo y, excepto unos pocos, todos encontraron acomodo en bancas metálicas y sillas de plástico sacadas de un almacén contiguo a la iglesia. En ese momento, los cofrades aparecieron luciendo un sencillo uniforme compuesto de pantalón o falda de color azul marino y camisa azul celeste. El hermano Lito, sus dos hijos adoptivos y otros cuatro miembros de la cofradía aparecieron vistiendo sotanas blancas de fino algodón atadas a la altura de la cintura por un cordón con tres nudos colgantes al estilo de los franciscanos consagrados. Sobre la mesa del altar descansaban tres grandes recipientes de cristal con líquidos, azulado uno, rosado y verde los otros, así como gran cantidad de candelas también de colores. Un pequeño pedestal a la derecha de la mesa fue ocupado por el hermano Lito, que comenzó con un largo discurso al que seguirían varias lecturas de la Biblia y una larga sucesión de testimonios de personas curadas, favorecidas o asistidas de cualquier otra manera por su fe en el poderoso hermano san Simón. Así hasta el amanecer.

La formalidad de los uniformes y las sotanas, así como la solemnidad del acto, en general eran novedosas 
con respecto a ediciones anteriores del cumpleaños de san Simón en el templo de Tamanique. El hermano Lito no tardó en dar razón de todo ello al comienzo de su discurso. En su acostumbrado tono, mezcla de humor, paternalismo y afecto, declaró ante su público con gran satisfacción: "Gracias a Dios tenemos los estatutos; estamos legalmente establecidos. Por eso ustedes van a ver [...]". Lito señala a un gran escudo situado en el centro del coro con una cruz de Caravaca sostenida por dos ángeles que la sacan del mar al mismo tiempo que el sol emerge; una estrella de siete puntas y una copa de cristal llena de un líquido azul completan la simbología del emblema. El hermano Lito lee en voz alta la leyenda que circunscribe el blasón: “[...] que dice: Iglesia Cristiana Espiritual de El Salvador. Legalmente tenemos treinta y dos artículos. Entonces pues, Gracias a Dios, logramos la personería jurídica y vamos para adelante". En ese momento alguien le pasa un documento a Lito, que muestra al público y, con evidente dificultad, comienza a leer: "Acá dice: Ministerio de Gobernación. Ramo de Gobernación. Acuerdo Ejecutivo 298. Aprobación de los estatutos de la Iglesia [...]". Lito interrumpe la lectura, pues confiesa que, a sus años, letra tan pequeña le supone un gran esfuerzo, y alguien en su lugar continúa leyendo el documento.

La decisión del hermano Lito está claramente destinada a equiparar su práctica espiritual a la pléyade de iglesias y asociaciones religiosas que, bajo el signo del protestantismo, el evangelismo, el pentecostalismo, el adventismo, el islam, etcétera, se han adaptado al marco legal proporcionado por el Estado para expresar y hacer prosperar propuestas religiosas alternativas a la todavía mayoritaria Iglesia católica. En su conjunto se trata de un movimiento de gran amplitud que, si bien tiene sus primeros antecedentes en los movimientos liberales de finales del siglo XIX, ya en las décadas de los ochenta y noventa del siglo XX ha conseguido revolucionar por completo el panorama religioso salvadoreño. Actualmente se estima en más de un cuarenta por ciento la población perteneciente a una u otra de estas iglesias no católicas, y probablemente la estimación se quede corta (Huezo, 2015).
El gesto no pasó inadvertido a los asistentes. Ante sus ojos, el culto a san Simón se estaba desmarcando de la legalidad católica a la que estaba fuertemente ligado por la tradición y se aproximaba a esa nueva y creciente configuración social que en El Salvador, y por oposición al catolicismo, se autodenomina cristianismo. Ciertamente la mayor parte de los asistentes, al ser preguntados, se declararon católicos, si bien es cierto que en las respuestas percibimos signos inequívocos de inercia, o simplemente de renuencia a entrar en sutilezas conceptuales.

La palabra católico aquí nos pareció funcionar como una especie de sinónimo de "costumbre". Y, efectivamente, como ya señalamos más arriba, la apariencia de la ceremonia central de la celebración del cumpleaños de san Simón es en su mayor parte tributaria de la tradición católica. La disposición de los componentes litúrgicos, el lugar asignado a cada uno de los participantes en el culto o el uso de uniformes se asemejan a la costumbre católica en un grado tal, que a veces parece sugerir cierta intencionalidad paródica. La Iglesia Cristiana Espiritual de El Salvador (ICES) también reconoce la existencia y omnipotencia de un dios único y benefactor. La Biblia ocupa un lugar privilegiado como vehículo del mensaje divino. Toda la corte espiritual sancionada por la Iglesia católica es aceptada por la ICES, pero con una considerable diferencia que es expresada en términos casi arrianos: Jesús no es dios y la Virgen, por tanto, es sólo madre de Cristo. El rango espiritual adjudicado a Jesucristo es compartido con el resto de los santos oficiales, los que han sido canonizados por el Vaticano, y con los apócrifos también. Santos apócrifos como el propio san Simón y otros personajes similares que, por lo general, en El Salvador y desde muy antiguo se conocen como hermanos y hermanas espirituales.

\section{Ciudad Arce}

Esta relación de continuidad entre deidades católicas oficiales y santos apócrifos esconde un fuerte principio organizativo que es completamente ajeno 
al catolicismo. Se trata de las "cortes" o "coronas espirituales", es decir, la agrupación de divinidades de acuerdo con las preferencias del devoto. Normalmente, uno de los santos establece una relación privilegiada con el creyente, una relación basada en afinidades emotivas que suelen implicar funciones protectoras por parte de la divinidad en cuestión. A partir de ahí, el santo permite el recurso a otros santos de acuerdo con las necesidades del fiel y la especialidad de tales santos. Dicha "corte" o "corona espiritual" puede llegar a incluir varias decenas de santos, entre los que predominan los apócrifos. En primer lugar están los salvadoreños, como Julio Cañas, Macario Canizales, Trinidad Huezo, Trema Adonay, Ernesto Interiano y un largo etcétera. Pero también hay espacio para iconos culturales de las más diversas procedencias: desde personalidades estrechamente ligadas al espiritismo positivista, como César Lombroso o Allan Kardec, hasta figuras míticas como Sansón y Juana de Arco, personajes de la mitología hindú como Krishna, Ganesh o Buda, e incluso celebridades recientemente fallecidas, como Lady Di o Sai Baba.

El hermano Lito forma parte del cuerpo de especialistas dedicados a estrechar lazos entre el mundo de los vivos y el de los hermanos espirituales. Se identifica a sí mismo con la elocuente expresión de "vaso". Su don se hizo manifiesto a la edad normal, a los siete u ocho años, y a partir de ahí comenzó una larga formación que ahora, a sus casi sesenta años, dice no haber completado del todo. Sus primeras lecciones fueron dedicadas a controlar tan poderosa facultad y limitar los momentos de tráfico entre las dos dimensiones de la realidad a un determinado número de horas por día para así evitar un desgaste excesivo. Pronto le quedó claro cuáles serían los hermanos espirituales de su predilección, los que le apadrinarían para el resto de su vida: "Ernesto Interiano de Santa Ana y Julio Cañas de Zacatecoluca".

La formación del hermano Lito también recorrió sendas más convencionales que le llevaron a cursar estudios en varios países, además de El Salvador, relacionados con técnicas de medicina alternativa, natural, ayurveda, quiropráctica, homeopática y espiritismo. Entre la poblada colección de diplomas que conserva en su consultorio - en el barrio Villa de Jesús de Soyapango, cerca del mercado municipalfiguran algunos expedidos en Colombia, Panamá, Guatemala y Estados Unidos. Sin embargo, su máximo grado de formación espiritual es el reconocimiento de los sacerdotes mayas de algunas de las principales cofradías de San Simón en Guatemala. El hermano Lito ha recibido la "vara" de los sacerdotes de Atitlán, de Zunil y de Itzapa. El reconocimiento por parte de estos sacerdotes mayas se consigue mediante varias pruebas, que incluyen también la recopilación de testimonios sobre las dotes curativas del candidato. El hermano Lito ha conseguido tres de estas varas, por lo que dice sentirse plenamente realizado y satisfecho.

El hermano Lito dice haber curado a miles de personas de todo tipo de dolencias durante sus cuarenta años de práctica. En Soyapango, además de la clínica naturista arriba mencionada, posee también un pequeño templo a San Simón donde cada domingo se reúnen algunos devotos. Pero también es dueño de un templo dedicado al hermano Julio Cañas en Ciudad Arce, a unos cuarenta kilómetros de la capital, en un fraccionamiento hecho en los años noventa en la parte baja del pueblo, en las inmediaciones de la carretera panamericana. El fraccionamiento o colonia se compone de unas cincuenta manzanas, aunque no todas están edificadas. Atraviesa todo el barrio un serpenteante río que en ocasiones abre sus vegas para el cultivo de pequeñas milpas, proporciona forraje para alguna que otra vaca que pudimos observar tranquilamente paciendo y también ofrece espacio para que niños y jóvenes jueguen a la pelota o simplemente retocen en la grama. Lito construyó primero un templo a principios de la década de los noventa y acaba de inaugurar un segundo edificio más amplio en sustitución del primero, que a partir de ahora se destinará a usos varios y a la consulta personalizada de los pacientes. El nuevo templo contiene en su altar un gran retrato de Julio Cañas, enmarcado en Perú con maderas bañadas en oro puro —ofrendado, según Lito, por un devoto del Ekeko-. A sus dos lados cuelgan retratos de Rosita Beltrán y 
Juana de Arco. Aquí celebran el cumpleaños del santo cada año en torno al 20 de noviembre. Lito confiesa, de nuevo, que su trabajo como vaso está guiado por Julio Cañas y que el peso adquirido por san Simón en los últimos años le ha obligado a darle más espacio y protagonismo que al propio Julio Cañas.

En la edición del año 2012 se hizo el mismo anuncio sobre el nuevo estatus legal adquirido por la ICES, sólo que en Ciudad Arce el hermano Lito contó con la presencia y apoyo ni más ni menos que del obispo de la Iglesia luterana salvadoreña, Medardo Gómez, con quien tuvimos oportunidad de mantener interesantes pláticas respecto a esta forma de cultura popular. De todas maneras, nos toca posponer su testimonio, así como las interesantes prácticas observadas en torno al culto a Julio Cañas en Ciudad Arce, y dejarlo para un momento posterior e independiente de este estudio sobre las devociones salvadoreñas a San Simón. ${ }^{2}$

La comunidad formada y liderada por el hermano Lito es numerosa, sigue creciendo y acaba de obtener el reconocimiento oficial que la constituye como Iglesia. El hermano Lito ha demostrado tener una gran confianza en sí mismo y en el legado de una tradición cultural salvadoreña mal reconocida, cuando no completamente invisibilizada. Sin embargo, el hermano Lito no es el único, ni siquiera el más representativo, de los exponentes de dicha tradición. Muchos otros templos a san Simón y a otros hermanos espirituales salvadoreños están esparcidos por toda la geografía del "paisito" de Centroamérica. A continuación analizaremos otros tipos de devoción con la intención de ampliar el rango de comportamientos y actitudes asociados con el culto de los hermanos espirituales. Ello nos permitirá ir adquiriendo una noción más comprehensiva de este curioso fenómeno cultural que, digámoslo de una vez, rara vez alcanza el grado de formalización conseguido por el hermano Lito. Ciertamente, la comparación nos permitirá valorar en su justa medida el esfuerzo legislador asumido por el hermano Lito. Sin embargo, la importancia del ejercicio comparativo consiste, ante todo, en mostrar las altas cotas de autonomía, libertad y creatividad que caracterizan esta expresión popular de la cultura.

\section{Cuyultitán}

Cuenta una de las muchísimas historias sobre la vida de san Simón que su estatua se le apareció milagrosamente al indio Felipe cuando se dirigía en romería a la fiesta de san Judas y san Simón en el valle de Zunil, espectacular paraje que comunica el litoral con las tierras altas de Guatemala a la altura de Quetzaltenango. ${ }^{3} \mathrm{Y}$ a pesar de que la onomástica festeje a Judas el Iscariote y a Simón el Zelote, por alguna extraña asociación de imágenes los devotos de san Simón son más dados a pensar que el Judas en cuestión es, en realidad, el que "traicionó al Señor por treinta monedas que luego repartió entre los pobres", y que Simón es en realidad el apóstol que "se vio obligado a negar tres veces a su Señor antes de que cantara el gallo". La asociación del san Simón centroamericano con el Judas traidor es aún más explícita en otros lugares de Centroamérica, donde es ahorcado y apedreado cada viernes santo (Mendelson, 1965; García Espada, 2015). San Simón en Centroamérica es un espíritu próximo, cuando no idéntico, a Judas Iscariote, si bien es cierto que los mismos devotos tienden por lo general a mostrar clemencia con la traición del apóstol; una traición que, a fin de cuentas, iba dirigida contra ese mismo dios que tan a menudo ha servido para justificar la arrogancia, el desprecio y la violencia ejercida contra la mayoría de la población. Esto decididamente suaviza la gravedad del crimen y a la vez contribuye a crear cierta afinidad entre el "pueblo" y la agenda del santo traidor. Sea como sea, hoy en día buena parte de la clientela de san Simón son los más pobres, los más vulnerables, los vendedores al menudeo, los homosexuales, los alcohólicos y las prostitutas. Sin duda, nadie como ellos es tratado hoy en día con tanta arrogancia, desprecio y violencia en Centroamérica. La festividad de todos ellos en El Salvador es el 28 de octubre.

En 2011, la celebración del cumpleaños del hermano san Simón en el templo de Will cayó en 29 por ser sábado. El templo de Will es más pequeño y el espacio circundante algo más reducido. Sin embargo, se encuentra en el centro de una población mediana de origen prehispánico, Cuyultitán -Coyulo para sus 
vecinos-, en el departamento de La Paz, a mitad de camino entre San Salvador y el aeropuerto de Comalapa, por lo que es mucho más accesible y recibe visitas continuamente a lo largo de todo el año. El templo es similar al de Tamanique pero, al ser de dimensiones más reducidas, resulta más acogedor. La imagen de san Simón está también situada en el altar pero a menor altura, y el devoto se encuentra al mismo nivel que el santo, por lo que se da una mayor intimidad en la relación entre ambos. En el templo de Cuyultitán no es raro ver al creyente mantener con la estatua de San Simón animadas conversaciones, que en ocasiones se convierten en agitadas arengas. A veces parece tan solo un intercambio de secretos, susurrados a la oreja del santo, al que además se acaricia y se besa en la mejilla.

La pared detrás del san Simón de Cuyultitán es un mural de unos ocho por cuatro metros que en 2011 estaba pintado con alegres colores que simulaban flores. El conjunto estaba bien mantenido y pintado de blanco y morado. De las paredes laterales cuelgan amplios retratos de Jesús como Divino Maestro, la Virgen de Guadalupe, Allan Kardec y los hermanos espirituales salvadoreños Julio Cañas, Trema Adonay, Margarita la Gitana, Ernesto Interiano, Emeterio Ruano, Raúl Lonchin y René Escalante. Hay, asimismo, otros dos retratos que ni los dueños ni los visitantes del templo dicen reconocer. En todos los casos se trata de fotografías antiguas de los años veinte, treinta y cuarenta del siglo XX, generosamente retocadas y coloreadas hasta el punto de hacer que algunas parezcan más pictóricas que fotográficas.

El templo está en el mero centro de Cuyultitán, a dos cuadras de la plaza del ayuntamiento, en el camino que desciende hasta el puente que salva un pequeño riachuelo que serpentea y se esconde entre las casas dispuestas a ambos lados de una suave quebrada incrustada en el centro de la ciudad. Dentro de la finca del templo se encuentran otras tres casas usadas por Will y su extensa familia como habitación y depósito de herramientas y almacén de granos de maíz y frijol. Will Torres es un voluminoso varón de unos cuarenta años de pelo y tez rojiza. En la dentadura aloja numerosas fundas de plata que dan a su amplia sonrisa un toque pícaro. Él se encarga de mantener las instalaciones y avivar el culto a san Simón. En el interior del templo tiene montada su consulta, en la que da servicio regular los jueves y los sábados de diez a doce de la mañana. Sus métodos son variados, aunque el propio Will reconoce que él no es un vaso, que sus técnicas preferidas son las cartas y la bola de cristal, y que su principal misión es mantener viva la obra de su "padre".

Fue el hermano René Escalante quien fundó el templo de Cuyultitán en los años ochenta del siglo pasado. Él sí fue un vaso y, en palabras de muchos de los que le conocieron, “el más vergón”. Al frente de otros treinta vasos más —entre los que estaba también el hermano Lito - fundó la Unión de Espiritistas Salvadoreños, que en 1980 recibió del Ministerio del Interior la personería jurídica. La Unión constaba de 39 artículos y su función primordial era: "Fomentar el conocimiento de la relación entre los espíritus y los hombres por los medios que tiene la ciencia espírita como son los Médiums", "Promover la superación cultural y elevación moral espiritual de sus socios y el conglomerado social", así como "Autorizar a ejercer su facultades a los Médiums oficiales y los Médiums auxiliares". El título está cuidadosamente enmarcado y expuesto en una de las paredes del templo de Cuyultitán. La Unión tuvo un recorrido corto. Los avatares de la guerra civil y las disensiones internas hicieron naufragar el proyecto. Sin embargo, el hermano René fue siempre reconocido por sus colegas y tuvo un gran número de seguidores que hoy, diecisiete años después de su muerte, siguen recordándolo con respeto y cariño. El hermano René tuvo la ocurrencia de dejar este mundo el 27 de octubre de 1998, un día antes del cumpleaños de san Simón. Sus restos están sepultados bajo el altar que ocupa la estatua del santo, en el templo que él mismo construyó en los tiempos de la guerra civil y bautizó con el significativo nombre de "La fe en la paz".

La construcción del templo también tiene detrás una historia sorprendente que nos contó el propio Will. El hermano René despertó una mañana embargado por un sueño. Se sintió compelido a desplazarse hasta la frontera con Guatemala - la de la Hachadura, en la carretera litoral - para recibir allí algo desconocido 
de alguien desconocido. Se trataba de una voluminosa caja que contenía la figura de san Simón desmembrada; una estatua particularmente realista, más parecida a un maniquí que a una talla de madera tradicional. Fue para contener y respetar el misterioso envío que el hermano René erigió el templo.

Esta curiosa historia sobre el origen del san Simón de Cuyultitán sirve también para mostrar su estrecha relación con el gran templo a san Simón en San Andrés Iztapa, en el departamento de Chimaltenango, Guatemala. Las celebraciones del cumpleaños allí siguen siendo las más celebres y multitudinarias de toda la región. En la edición de 2013 tuvimos la oportunidad de constatar la enorme afluencia de personas de toda Centroamérica, e incluso de México, si bien me dio la impresión de que la salvadoreña era, después de la guatemalteca, la nacionalidad más representada. La fiesta se extendió durante tres días consecutivos y ni las copiosas lluvias ni su coincidencia con días laborales - la cofradía de Iztapa celebra el cumpleaños en su día aunque sea laboral, como ocurrió en ese año- redujo el flujo de visitantes. La celebración ahí presenta importantes diferencias con las celebraciones documentadas en El Salvador; por ejemplo, el uso de armas de fuego para homenajear al santo con tiros al aire, la quema de gallinas vivas a modo de sacrificio o el ansiado baile con la vara del santo, que da lugar a enormes filas de pacientes devotos que esperan su turno en medio de muchos nervios y gran expectación. Sin embargo, nada está más en consonancia con san Simón que la extraordinaria variedad local y microlocal de las prácticas asociadas a su culto. Volvamos pues a El Salvador.

El hermano René, al igual que el hermano Lito, no tuvo hijos naturales. Los hijos del segundo, a los que nos referíamos en el anterior apartado, Julito y Alex, perdieron a su padre biológico durante la guerra civil de la década de los ochenta y fueron adoptados por el hermano Lito. Will también era un niño de la calle que fue acogido por el hermano René y que, tras su fallecimiento, quedó como heredero único. Desde entonces, el compromiso de Will con su padre espiritual ha sido inquebrantable. No ha habido año que se haya dejado de celebrar el cumpleaños de san Simón, que en
Cuyultitán está cargado de una emotividad doble. A tal efecto, Will no repara en gastos. Cada año el templo es enlucido y decorado con profusión de flores naturales y artificiales. El terreno donde se asienta el complejo es nivelado con tierra y apisonadora en la víspera de cada fiesta. El día del cumpleaños, Will prepara comida, bebida y diversión para más de quinientas personas, una cifra que se ha ido ampliando cada año y que en la fiesta de 2014 superó los mil asistentes.

La financiación de tan costoso evento tiene tres cauces: por una parte, los ingresos que Will obtiene a lo largo del año como consultor espiritual y solucionador de dificultades; por otra, los ingresos obtenidos de la venta de maíz y otros productos agrícolas que el propio Will cultiva en terrenos anualmente arrendados y, por último, las donaciones privadas. Es frecuente ver las imágenes de san Simón cargadas de billetes de circulación legal que unas veces son depositados en el regazo del santo y, otras, habilidosamente engarzados entre sus dedos. Además, en el templo cuidado por Will, a la par de la imagen del santo, cuelga una pequeña alcancía de madera en la que se lee: "Regálame un dólar para mi fiesta". Will Torres dice no llevar contabilidad alguna de los ingresos y gastos relacionados con el culto a san Simón. Seguramente lo haga para proteger su convicción de que el dinero llega milagrosamente, siempre que sea para gastarlo en las atenciones y cuidados que merecen su padre espiritual, René Escalante, y el hermano san Simón.

Las celebraciones del templo de Cuyultitán están fuertemente inspiradas en la larga tradición local de festejos religiosos. Uno de los elementos clásicos es la procesión por las calles del pueblo. Una imagen de sustitución de San Simón - la original es demasiado valiosa para exponerla a los riesgos de un paseo nocturno- es encaramada en lo alto de una pickup seguida de músicos, cohetes y un cortejo de varios cientos de personas entre devotos y vecinos del pueblo. Otro clásico de las fiestas populares centroamericanas es la matanza del cerdo. El hermano Will tuvo reservado en el año 2011 un estupendo ejemplar de casi cien kilos, con el que se hizo caldo y tamales para cubrir los tres tiempos de comida de todos los asistentes. El 
ineludible elemento musical de la fiesta fue atendido por una nutrida orquesta que amenizó la jornada diurna con cumbias, salsas y rancheras hasta bien entrada la tarde, momento en el que la música artesanal fue sustituida por otra más industrial. Al filo de las ocho de la noche empezó a funcionar una discoteca móvil con una sofisticada mesa de mezclas conducida por un DJ profesional y varios miles de voltios arrojados desde ocho imponentes cajas de sonido que mantuvieron a más de un centenar de personas bailando hasta bien entrada la madrugada.

En su conjunto, la fiesta se desarrolló en total consonancia con la forma y el ambiente que anima el templo de Cuyultitán, un templo abierto a todos, donde la imagen del santo es completamente accesible, sin defensas ni coros, sin vitrinas que lo protejan y situado a la altura de los ojos del visitante. De igual manera, la fiesta se caracterizó por la diversidad y armonía entre los distintos ambientes. A diferencia de la celebración de Tamanique, la de Cuyultitán no tenía un único foco de atención, sino varios. Mientras unas personas hacían cola para pasar a platicar con el santo, otros mantenían triviales charlas en algunas de las mesas de plástico distribuidas azarosamente por toda la parcela. Unos bailaban aquí al son de la orquesta y "algotros" allá fumaban sus puros concienzudamente. Hubo un único conato de unanimidad alrededor de las ocho de la noche, en el momento en que la megafonía anunció la entrada en la pista de baile de un grupo especial de "lindas señoritas". Una docena de apuestos jóvenes, abundantemente maquillados y ligeramente vestidos, se abrieron paso por el estrecho corredor formado por la arrobada multitud. Tan pronto subieron los decibelios que daban salida a los primeros acordes de una conocida cumbia, las "señoritas" pusieron en marcha una sofisticada coreografía plagada de acrobacias y movimientos decididamente sexys. La excitación entre los asistentes se hizo evidente no sólo por el griterío y los aplausos; no fueron pocos los asistentes varones que se lanzaron a la arenosa pista de baile, alguno a replicar los pasos de las bailarinas y otros sencillamente a intentar poner en contacto alguno de sus miembros con alguna parte del cuerpo de las artistas travestidas.
La megafonía no tardó en intervenir de nuevo solicitando la contención y el decoro de los asistentes: "Compañeros, por favor, respeten a las señoritas, que son personas como todo el mundo". A esas horas el alcohol había corrido abundantemente por la fiesta y, aunque la mayoría de los asistentes demostraba tener buena capacidad de resistencia, no faltaban los parroquianos completamente entregados a las veleidades del guaro. Sin embargo, el llamamiento hizo su efecto y en adelante predominó el trato cortés hacia los transexuales. No es que el proverbial machismo homofóbico de las sociedades latinoamericanas se disipara por completo. Algunas de las personas se retiraron de la escena del baile pocos minutos después de satisfacer su curiosidad inicial. Otros parecieron molestarse por el "descaro" de las travestidas, pero supieron encontrar la manera de desviar su atención hacia propósitos más elevados. En la celebración del cumpleaños de San Simón no caben distinciones. Todos somos iguales, hijos de un mismo dios y devotos del mismo santo. Y, efectivamente, la noche transcurrió con total tranquilidad, sin disturbio alguno. Tras la espectacular aparición, el grupo de transexuales se integró a la masa, que siguió durante horas bailando al son de los ritmos electrónicos. Por lo general predominaron la simpatía, la improvisación y las bromas. Durante unos momentos, uno de los grupos más denostados y marginados de la sociedad salvadoreña tuvo la oportunidad de lucirse en público y recibir el respeto de una multitud alegre y, al menos durante unas horas, unida en torno a la figura del hermano san Simón.

Entre los entrevistados en la fiesta de Cuyultitán encontramos carpinteros, albañiles, fontaneros, meseros, vendedoras — algunas que conocíamos del Mercado Central de San Salvador-, campesinos, prostitutas, curanderos, brujos y personas con otras ocupaciones típicas de las clases medias-bajas de El Salvador. No faltaron tampoco los niños que, formando bandadas, atravesaban con sus risas y travesuras los diferentes ambientes de la fiesta. Cabe destacar la presencia de numerosos habitantes locales, del propio pueblo, que a menudo hacían aparición para luego volverse a ir y regresar "al rato". Eso hizo todavía más difícil aislar algún tipo de elemento social predominante. 
Pero es cierto que la trinidad tradicionalmente asociada con san Simón - prostitutas, homosexuales y alcohólicos - no faltó a su cita de Coyulo. Uno de los actos más emotivos fue la generosa serie de corridos que un trío de Alcohólicos Anónimos interpretó en honor y agradecimiento al santo. Los temas cantados por el grupo, con sentida nostalgia y admirable maestría, contaban las cuitas de mojados, contrabandistas y otras víctimas de la justicia terrenal, y su actuación se prolongó hasta altísimas horas de la noche. Me pareció que en el fondo estaban pidiendo permiso y bendiciones al santo para conseguir la desintoxicación.

Una de las actividades más recurrentes y llamativas de la celebración de Cuyultitán fue la práctica conocida como "purear". La combustión de tabaco puro se realizaba bien en solitario, o en pequeños grupos dispuestos en corro. El fumador se sienta con el cuerpo ligeramente inclinado hacia adelante. En el suelo y entre los pies sitúa un pequeño guacal o una teja de barro cocido donde cae la ceniza del puro. Éste es inhalado con vehemencia, sin apartarlo de la boca, generando gran cantidad de humo mientras el practicante se concentra con intensidad en su duda, su problema o su objeto de deseo. Las peculiares marcas que tan veloz combustión va dejando en el cigarro, así como la disposición de la ceniza que cae al recipiente apostado en el suelo, contienen la información requerida sobre cuál será el mejor curso de acción en la resolución del conflicto o en la consecución de los deseos. Sus usuarios lo consideran una técnica directamente relacionada con el manejo de los cuatro elementos esenciales: la hoja de tabaco es la tierra, el humo es el aire, la brasa el fuego y, a su paso por la boca, la saliva simboliza el agua. Alguno de los asistentes ofreció su guía a los integrantes de este grupo de investigación. Pero en general, cada uno de los practicantes parecía contar con la ciencia necesaria para optimizar sus propios recursos y las consultas se limitaban al intercambio de opiniones. Me pareció que la extrema subjetividad de todo lo relacionado con la práctica de purear es un fuerte estímulo al desarrollo de la creatividad y la imaginación a la hora de buscar soluciones prácticas a los problemas tangibles.

Una de las escenas más llamativas en relación con la práctica de purear fue la de una mujer de avanzada edad y toda vestida de negro, con una larga peluca rubia, oscuras gafas de sol ocultando la mayor parte del rostro y enormes uñas postizas también negras. Vestía con cierto lujo un traje de chaqueta y pantalón ajustado imitación de cuero. La acompañaban dos jóvenes impecablemente vestidos con saco y corbata que parecían estar al servicio de la misteriosa dama. Durante el tiempo que duró nuestra observación, consumió siete puros seguidos uno tras otro, sin apartárselos de los labios más que para expulsar de vez en cuando los excesos de saliva con un rápido y seco escupitajo hacia el lado izquierdo. Mientras tanto, con la mano izquierda efectuaba enérgicos gestos consistentes en agitar y chascar los dedos generando breves golpes secos. Con ello parecía aliviar la tremenda concentración de calor en la boca generado por tan frenética combustión de tabaco puro. Nos bastó con registrar la mirada de la señora para captar su total renuencia a ser entrevistada.

Otra de las escenas que produjo una fuerte impresión en nuestros ojos fue la de un joven devoto de entre 16 y 18 años acompañado de su novia y de un revólver, del que descargó cada una de sus balas en presencia del santo. Primero pasó todos los proyectiles por el regazo de la imagen y, a continuación, se frotó todo el cuerpo con un ramillete de varias yerbas impregnadas en agua perfumada, deteniéndose con mayor cuidado en las partes del cuerpo más vulnerables a los disparos. Nuestro asombro fue correspondido con una cómplice sonrisa por parte del individuo y con la más completa indiferencia por parte del resto de los parroquianos presentes.

En medio de este variado paisaje, la fiesta siguió adentrándose en la noche dejando numerosas bajas por todas partes. Los niños, extenuados por sus carreras, empezaron a ser acomodados en rincones, pegados a las paredes o entre los pliegues de los frondosos árboles de la finca para evitar ser pisoteados. El otro gran contingente de dominados por el sueño fue el de los borrachos, que para dormir a veces no requirieron infraestructura alguna. Unos, con recostar su cuerpo sobre una mesa quedaron satisfechos, y otros, simplemente con alcanzar el necesario grado de equilibrio, tuvieron bastante con 
una silla para pasar las últimas horas de la noche entre dulces sueños. En cualquier caso, la idea de la vigilia no fue tomada por el conjunto de los asistentes como una firme exigencia, sino más bien como una intención acompañada del propósito de "pasarla bien", que es lo que el san Simón de Cuyultitán espera de sus devotos.

\section{San Pedro Masahuat}

Sin duda la celebración del cumpleaños de san Simón de 2011 en el templo de Will Torres fue irrepetible, pero no única. Ese mismo día se arman fiestas similares en otros lugares de El Salvador que hemos tenido oportunidad de visitar durante el periodo de esta investigación, como el templo de la hermana Marina en Aguilares (San Salvador), el templo de la hermana Romy en San Francisco Gotera (Morazán), el templo de la hermana Carolina de San Vicente, el templo de la hermana Adelina en San Ramón (Cuscatlán), el templo del hermano Félix en la Hacienda Jayuca (La Libertad), los templos del hermano Lito en Tamanique y Ciudad Arce ya referidos y los templos del hermano David Alfaro en la colonia Cinco de Noviembre de San Salvador y el de la hermana Julia Abarcas en San Pedro Masahuat, departamento de La Paz, de los que nos ocuparemos a continuación.

Hay en el país otros lugares, que aún no hemos tenido oportunidad de conocer, donde se celebra puntualmente la festividad de san Simón cada año y con capacidad de convocar desde un grupo de amigos, hasta varios cientos de personas. A veces, sin embargo, algunos de los hermanos propietarios de estos templos deciden juntarse y compartir la festividad en una única localización. Esta suerte de intercambios son vividos por los propios participantes como una especie de ecumenismo que ha de sobreponerse a diferencias "litúrgicas". Cada una de las comunidades conformadas en torno a la celebración del cumpleaños desarrolla comportamientos y actitudes diferentes que deben ser puestas a un lado cada vez que se decide compartir la fiesta. No siempre se logra.

En la edición de 2011, la hermana Julia Abarcas y el hermano Lito unieron esfuerzos y públicos para celebrar el cumpleaños de san Simón. Hubo, sin embargo, un aspecto sobre el que se levantó desacuerdo. La fiesta tuvo lugar en las instalaciones de la hermana Julia en San Pedro Masahuat y logró que asistieran más de ochocientas personas para las que fue sacrificado un hermoso buey. El problema surgió por una banda de bailarinas profesionales que fueron contratadas por uno de los devotos y que, como parte de la ofrenda a Monchito, orquestaron un estriptis completo que no gustó al hermano Lito. Éste, junto con su séquito, decidió abandonar la fiesta sin cumplir la vigilia entera. Sin embargo, el desacuerdo entre ambos líderes no duró mucho. Al año siguiente, noviembre de 2012, fue la hermana Julia la que se unió a la celebración del cumpleaños del hermano espiritual Julio Cañas preparada por el hermano Lito en el templo de Ciudad Arce. Julia pidió disculpas y aseguró que no era su intención ofender a nadie y que ni siquiera ella conocía los planes del devoto - que en lo personal seguía considerando respetable- La anécdota llegó a nuestros oídos desde las dos perspectivas involucradas en el conflicto y nos quedó claro que la reconciliación fue sincera.

Julia Abarcas es otro vaso. Nacida en 1942, ha sido madre de trece hijos y abuela ya de veintinueve nietos. Parte de su descendencia está en Estados Unidos, pero la mayoría vive en El Salvador dedicándose "a la cuma”, en alusión a la condición de jornaleros, intrusos o "paracaidistas", como se les llamó alguna vez, dedicados a la subsistencia, sin propiedad ni título legal alguno sobre la tierra que trabajan. Quedó viuda durante la guerra, pero justo antes, en 1979, Julia descubrió su don. Su caso es particular pues su reconocimiento no llegó hasta alcanzar una avanzada edad, a los 37 años y ya con diez hijos. Fue su "medio primo", el hermano René Escalante, quien la inició en su formación como médium, y llegó a convertirse en una de sus principales asistentes durante catorce años. Sin embargo, tocó a Will heredar el principal legado de René, el templomausoleo de Cuyultitán, y, aunque es posible que eso levantara cierta suspicacia entre ellos, hoy Will y Julia también mantienen buenas relaciones. Aquí de nuevo el temperamento de Julia debió ser fundamental. La 
anciana señora es de un trato especialmente afable, de rostro y gesto solemne, aunque constantemente suavizado por una sonrisa siempre presta a convertirse en contenida carcajada.

Julia no sabe leer. Eso, dice con resignación, la limita en su práctica, por ejemplo, a la hora de ejecutar ciertas fórmulas y oraciones. Sin embargo, su fuerte son las plantas. Con ellas habla y a ellas se refiere como si de personas se tratara, marcadas no sólo por cualidades, sino también por un determinado carácter que las hace versátiles y susceptibles al trato que se les da. Tiene muy buena relación con la sábila, pero no así con la ruda, con la que últimamente tiene problemas pues es caprichosa y, aunque le haga bien a sus pacientes, de una u otra manera acaba también perjudicándolos. Julia nos dejó encantados con su generosa plática y sus amables intenciones, si bien su dulzura a veces funcionó como parapeto de medias respuestas y salidas por la tangente. En su descargo, cabe mencionar que la propia Julia ha detectado los efectos de un incipiente deterioro de la memoria al que quiso referirse, sin conseguirlo, con el impronunciable nombre de un célebre neurólogo alemán. Julia es vegetariana, aunque a veces come pollo porque se lo pide el espíritu de alguno de los hermanos cuando entra en comunicación directa. Sus santos preferidos son Macario Canizales, Julio Cañas, Lonchin, Sansón, Margarita la Gitana, Rosita Beltrán, Buda y Ganesh. Siente cercana la hora de la muerte y le está pidiendo, implorando, al alcalde de San Pedro Masahuat que le dé permiso para ser enterrada en el templo que en 2003, "gracias a Dios", consiguió levantar en homenaje a San Simón, en una parcela que no le pertenece pero que a día de hoy nadie ha reclamado todavía — según los registros, el titular podría ser el Ministerio de Defensa-.

\section{San Salvador}

David Alfaro es un apuesto varón de unos cuarenta años de edad, siempre vestido de escrupuloso negro con el que dice protegerse de la envidia y otras sutiles energías destructivas. Su templo es el más llamativo de todos los que hemos tenido oportunidad de visitar. Situado en un céntrico barrio de San Salvador, entre las calles Cinco de Noviembre y Veinticinco Oriente, el edificio es independiente y consta de dos alturas: una primera que sirve de consultorio general, con una sala de espera con ciento cuarenta sillas de plástico bien alineadas, una botica con plantas medicinales, inciensos, aguas perfumadas y candelas, y una pequeña sala oscura donde el hermano David atiende a los necesitados desde el otro lado de una mesa baja, con una gran copa de agua en el centro que también tiene funciones protectoras. La segunda planta contiene varias estancias: una destinada exclusivamente a candelas y veladoras con un extractor de humos, otra más grande que da a un balcón abierto donde se purea y otra con numerosos retratos de hermanos espirituales - unos cuarenta-y estatuas de bulto de Macario Canizales, Trinidad Huezo, la Santa Muerte, la Virgen de Guadalupe y varias de Judas Tadeo. En una cuarta sala se aloja un imponente san Simón de tamaño y gesto humano, de madera sin policromar pero tiznada por el humo. Lo más impactante, sin embargo, es la fachada del edificio, reformada en enero de 2013 y preñada de elementos decorativos decididamente kitsch: amplias molduras, series de pilastras, tondos, rosetones y arcos de madera pintada de color oro simulando bajo relieves, y entre medias tres grandes pinturas de san Simón, Guadalupe y Judas Tadeo sobre un brillante fondo blanco. La misma filosofía decorativa caracteriza el interior del consultorio, donde cada pared exhibe símbolos de varias religiones universales: islam, judaísmo, budismo, así como deidades mayas y varios crucifijos, todo ello con una clara pretensión teosófica.

El hermano David pasa consulta todos los días del año. La gente es atendida en estricto orden de llegada $y$, por lo general, antes de las ocho de la mañana ya están asignados todos los números -el límite es de 180 consultas al día-. La mayoría de los entrevistados decían acudir al especialista por cuestiones de salud. Las consultas son gratuitas y el pago es sólo por los productos adquiridos para llevar a cabo el ritual prescrito; hay que añadir que los precios de dichos productos son muy ajustados y casi iguales que en el mercado. En eso no es muy diferente de otros centros terapéuticos, cada vez más abundantes en el centro y las 
periferias del norte y el este de la capital. Ciertamente, la cantidad de personas atendidas diariamente por el hermano David es asombrosa y el templo de la Cinco de Noviembre sirve también para la celebración del cumpleaños de san Simón.

Por su situación, en un barrio muy expuesto al dominio de las pandillas, entre los ayudantes del hermano David hay varios fornidos varones de gesto intimidante y vestidos como "mareros". Son ellos los que, apostados a la entrada, reciben a los pacientes y reparten los turnos. Inicialmente su actitud es hostil, y eso nos dificultó considerablemente el acceso al hermano. Sin embargo, una vez conseguido y ya después de la primera entrevista, el personal de seguridad cambió radicalmente de actitud y se mostró amable, familiar y jocoso. Alguno de ellos resultó ser uno más de los miles de salvadoreños deportados diariamente desde Estados Unidos e hicieron referencia a las cárceles de aquí y de allá donde, según aseguraron, el culto a san Simón también es creciente. El trabajo de los asistentes de David no es sólo policial; también cumplen funciones más significativas como, por ejemplo, ejecutar las "limpias" que tienen lugar en el templo una vez al año, el día más auspicioso según los cálculos del hermano. Estas limpias son operaciones sobre la energía sutil del cuerpo, para depurarla o prepararla para misiones más elevadas. Por lo general, el interesado se para delante del experto, que pasa un ramillete de plantas - las siete yerbas, la ruda, etcétera- mientras derrama en abundancia algún líquido —es conveniente que sea espumoso como, por ejemplo, cerveza o refrescos, como el local Kolashanpan- desde la coronilla a los pies, a la vez que uno recita una serie de fórmulas rituales y, el otro, se concentra en su deseo o propósito. Las limpias a veces terminan con el rociado de algún tipo de aguardiente que el especialista introduce en su boca y escupe enérgicamente contra el rostro y el pecho del paciente.

David habla pausadamente, con dicción clara y capacidad para conversar sobre todo tipo de asuntos, algunos de la más variada actualidad. Su puesta en escena es ciertamente intimidante: el traje oscuro, la sala en penumbra, el copón de agua sirviendo de parapeto, los fornidos asistentes que dejamos atrás... Sin embargo, hablamos con él largo y tendido y no puso ninguna objeción ni al contenido de la entrevista ni al uso de una grabadora electrónica. Aun así, desde el primer encuentro tuvimos la impresión de estar robándole un tiempo precioso. El hermano David cree vehementemente en su misión, una misión que le ha sido asignada desde su nacimiento y que, con el paso del tiempo y su profundización en la práctica espiritual, le es cada vez más clara. Dice que san Simón es un "espíritu de luz que ayuda en todo" y que recientemente -2012 - acababa de "ascender espiritualmente" debido a la gran acumulación de gente ayudada por el santo. Más que vaso o médium, se prefiere llamar a sí mismo "materia". A la hora de nombrar su práctica se refirió en todo momento al "espiritismo". Sin embargo, pudimos comprobar que no tiene conocimiento de algunos de los maestros clásicos del espiritismo positivista, como su propio fundador Allan Kardec. En cambio, sí tenía nociones más o menos precisas de las doctrinas del karma y la reencarnación, de santería y algo de teosofía. Su nombre completo, nos confesó, es David Alfaro Duarte Langlois, y eso le hace pensar que por sus venas corre sangre francesa que lo conecta con una cultura espiritual universal dentro de la cual, dice, la salvadoreña de los hermanos espirituales no se distingue en nada esencial.

\section{Sonsonate}

El último escenario del que nos vamos a ocupar en este estudio se encuentra en el cantón $X$ del municipio Y del departamento de Sonsonate. Hasta ahí llegamos en un potente vehículo con tracción en las cuatro ruedas, por un largo camino de terracería mal conservada con pronunciadas pendientes y descensos que apenas lograban salvar con algo de dignidad las numerosas quebradas que dominaban el paisaje. Los aproximadamente veinte kilómetros cubiertos de esa forma consumieron más tiempo que el desplazamiento desde San Salvador a la cabecera del municipio. A partir de ahí el camino se bifurcaba continuamente, dejando a nuestro paso numerosas áreas habitacionales pequeñas 
y semiocultas por una espesa vegetación. El destino final estaba situado en la cornisa de un amplio cañón por el que discurría, a unos cuarenta metros de profundidad, un caudaloso torrente flanqueado de árboles y plantas en el estado de exuberancia obligada al final de la estación lluviosa. La cima del acantilado estaba recorrida por un camino flanqueado a ambos lados por parcelas dispersas, separadas de la vereda por alambres de espino pero sin divisiones aparentes entre ellas. No pudimos establecer ninguna regularidad en la construcción de las viviendas: hechas de bloque, bahareque, lámina, ramas o escombros, y de proporciones y dimensiones también muy variadas. Entre los habitantes observamos niños, muchos de ellos desnudos, y adultos también descalzos $y$, en el caso masculino, descamisados y con pantalones cortos - referidos localmente como chorcitos-.

Nuestro contacto, Luis, ${ }^{4}$ es un joven de veinticinco años natural de ese idílico paraje, pero que desde hace unos cinco años vive y trabaja en un negocio hostelero de la playa en el departamento de La Libertad. Luis aceptó formar parte de esta investigación bajo condición de que su nombre y los detalles del lugar estudiado no fueran hechos públicos. Tampoco se nos autorizó a hacer registro audiovisual de ninguna clase. La familia de Luis es extensa y el padre está tocado por el don de la curandería. A nuestra llegada fuimos recibidos por un grupo de unos ocho varones de elevada edad que, a pesar de las cortesías gestuales, apenas nos dirigieron la palabra. No obstante, tuvimos ocasión de constatar en sus conversaciones privadas el uso del náhuatl acompañado de expresiones en castellano.

Tras darnos un breve recorrido por el lugar para mostrarnos con orgullo algunos de sus cultivos y cosechas - en especial el extraordinario elenco de gordas semillas de maíz nativo de variados colores-, Luis y un familiar, que no dio su nombre, nos condujeron por una estrecha trocha en pronunciado descenso hasta el fondo del barranco. Unos diez metros antes de llegar al lecho de la quebrada se encontraba nuestro verdadero destino, una cueva natural sobre la pared del acantilado, cerrada por un semimuro de bloque y una estrecha puerta metálica. El espacio creado era circular, con una altura media de entre dos y tres metros y coronado en el centro por un círculo de piedras y cenizas. Con nosotros transportábamos los instrumentos necesarios para reactivar el fuego que convertiría la cueva en un temascal. Se trataba de algunas ramas secas y un buen número de velas, inciensos y tabaco en forma de puros. En total éramos seis las personas en el interior de la cueva, que en caso de necesidad podría dar cabida a más de veinte personas bien acomodadas. En el fondo de la cueva se veía excavada una pequeña hornacina donde únicamente reposaba un sencillo marco de madera que contenía la imagen en blanco y negro de san Simón.

El fuego preparado por Luis y su asistente tardó poco en sacar el humo de las velas, los inciensos y los puros, que se esparció hasta saturar por completo la amplia cámara. No pudimos aguantar el sofoco durante más de media hora seguida. Luis nos dijo que se trataba de un temascal seco y que, a diferencia del temascal de vapor, los efectos terapéuticos eran más efectivos y radicales. Y, efectivamente, pasamos por momentos rayanos en la angustia. La ceremonia estuvo caracterizada por la falta de comunicación verbal, la búsqueda de concentración en el baile de las llamas y el humo, la pronunciación de algunas oraciones en castellano y en náhuatl, así como por la formulación de peticiones al fuego. El rito estuvo aderezado con unos tragos de chaparro, un potente aguardiente extraído de sucesivas destilaciones del maíz y cuya producción, circulación y consumo aún sigue prohibido en El Salvador.

Al terminar, descendimos un poco más hasta llegar a un nacimiento de agua cercano que brotaba de la pared y era contenido por una pequeña pileta donde aprovechamos para refrescarnos y reoxigenarnos. A partir de ahí, la tensión inicial entre nosotros y los informantes comenzó a disiparse y la conversación se hizo más fluida. Lo cierto es que hasta ese momento, aparte de la imagen, no hubo apenas alusiones a san Simón. Sin embargo, él era la deidad encargada de la protección y la guía del temascal. Se trataba, siempre según Luis, de una práctica ancestral. Aunque el muro y la puerta eran de construcción reciente - unos diez años-, la cueva era utilizada como temascal "desde siempre", y "desde siempre" había estado presidida por san Simón, a quien dedicaban una fiesta especial los 
días 28 de octubre, que se celebraba dentro del propio templo-temascal. Luis confesó que san Simón era el san Judas de los indígenas en El Salvador. Ante nuestra pregunta de a qué san Judas se refería, Luis respondió, algo confundido, que no conocía de la existencia de otro Judas. En un intento por clarificar aún más su respuesta, insistió en que, con la celebración de su fiesta el día de san Judas, san Simón no hacía otra cosa que "despistar a sus enemigos".

A pesar de que volvimos a tener oportunidad de encontrarnos con Luis, no fueron demasiados los datos etnográficos recabados en relación con el culto a san Simón, ni de éstos se desprendió una variante significativa dentro de esta práctica religiosa a escala nacional. No hubo oportunidad de contrastar la comunicación de Luis con otro tipo de fuentes orales, y mucho menos escritas. Ni siquiera intentamos rastrear sus orígenes ni su evolución, ni tampoco las relaciones establecidas por la familia de Luis con diferentes modalidades del culto a san Simón desarrolladas por otros devotos. El marcado hermetismo de nuestro informante nos hizo dar por bueno todo aquello que espontáneamente quiso compartir con nosotros. Sin embargo, la decisión de incorporarlo a esta investigación tiene su razón de ser, primero, por la excepcionalidad de lo observado y, segundo, por su incardinación en un universo social muy próximo a la extinción. Para empezar, se trata del único temascal genuino al que he tenido acceso en todo El Salvador. Ciertamente, el área, el departamento de Sonsonate y el departamento de Ahuachapán, y en especial los municipios de Nahuizalco, Santa Catarina Masahuat, San Pedro Puxtla, Guaymango o Santo Domingo de Guzmán, constituyen losúltimos espacios del occidente salvadoreño donde la lengua y otros importantes rasgos culturales de origen náhuatl han logrado sobrevivir. Ciertamente se trata de una supervivencia muy precaria, en particular desde los trágicos hechos de enero de 1932 y el ahondamiento en el profundo trauma salvadoreño relacionado con el blanqueamiento de la raza y la formación del Estado moderno.

En el entorno de Luis el miedo sigue activo, un miedo acaso solidificado en forma de precaución sistemática y que, en buena medida, caracteriza toda una actitud vital. Sin duda, su más evidente y triste expresión es la renuencia a hablar náhuatl, especialmente en público. Sin embargo, las últimas investigaciones sobre tradiciones pipiles supervivientes demuestran la continuidad de cultos mistéricos y de relaciones muy íntimas con la tierra y el agua, los árboles y las cuevas, los ciclos periódicos y los sobresaltos de la naturaleza. Aquí san Simón parece cumplir una función específica y directamente relacionada con formas de resistencia desarrolladas en los primeros contactos con la modernidad. Son particularmente interesantes a este respecto las tradiciones orales relacionadas con el kuhkul o guhkul (Lemus, 2015). Se trata de un hombre blanco, con sombrero y normalmente a caballo, ${ }^{5}$ con poder y por lo general mentiroso. Tiene la facultad de cambiar de apariencia y de "jugar" al indio para llevárselo al inframundo, un inframundo al que se accede a través de una cueva, que es como la vagina de la tierra, por la que salen los seres vivos y regresan los muertos. Esta especie de puerta interdimensional comunica dos mundos de manera ordenada, aunque dicho orden también puede ser revertido. La posibilidad la brindan personajes como el kukhul que, si bien desde la óptica cristiana no es otro que el diablo, desde la perspectiva pagana — del pagus - conserva un importante papel como intermediario entre dos dimensiones necesarias de la vida cotidiana. El acceso al inframundo puede proporcionar la mejor solución posible a los problemas cotidianos, puede servir como contrapartida a las injusticias de este mundo; puede, en suma, ayudarnos a aprender a vivir mejor.

Luis así lo cree, pero también lo considera un privilegio exclusivo de los suyos. En ningún momento fuimos invitados a la celebración del cumpleaños de san Simón y, como dije más arriba, los mayores de la comunidad rehusaron, muy amablemente, a formar parte de esta investigación y compartir con nosotros detalles de su vida privada. Pero más allá de fenómenos históricos de profundo y traumático calado, nos pareció detectar razones más inmediatas para tan excluyente actitud. La comunidad objeto de nuestra observación de campo resultó ser una isla de resistencia en mitad 
de un océano de comunidades pentecostales que en los últimos veinte años han acabado predominando en el área de manera incontestable. De hecho, Luis y su familia se ven a sí mismos como los últimos católicos y guardianes de la "costumbre". La presión de sus vecinos es constante y creciente, y el principal punto de fricción es, precisamente, la fe en los santos y sus imágenes. Los argumentos - defendidos desde los modernos pulpitos católicos y ampliamente reproducidos por los parroquianos de a pie cuando son confrontadosrespecto a la supeditación de las imágenes a los santos y su condición de simples recordatorios, no sirven para la defensa de san Simón. Su imagen, más que una representación, es en sí misma una fuente de poder: la "trasferencia de la revelación a la materia" (Taracena, 2008: 73). Luis y los suyos la protegen celosamente contra todos, contra pentecostales y católicos post-Vaticano II por igual. Y es precisamente esa actualización del kukhul pipil en la forma de un señor sentado, con bigote, sombrero, saco y corbata, que fuma puro y toma guaro, la que parece cumplir una función significativa en la expresión y afirmación de esa especificidad tan tenazmente defendida por Luis y los suyos.

\section{Conclusión}

La celebración del cumpleaños de san Simón es una buena oportunidad para observar comportamientos y fórmulas sociales que en El Salvador, por lo general, pasan desapercibidos o son conscientemente ignorados. En este escrito hemos puesto énfasis en señalar la extraordinaria plasticidad del culto a san Simón. Los casos expuestos bastan para comprobar la pluralidad de comportamientos desplegados en torno a su culto, la extraordinaria diversidad de técnicas espirituales empleadas e, incluso, de cosmovisiones implicadas. Sin duda, cierta voluntad contracultural permea todas estas manifestaciones, que sin mayor controversia podemos caracterizar en su conjunto como una manifestación de "sincretismo espontáneo" —en oposición al "sincretismo guiado" por parte de instituciones como la Iglesia o el Estado (González 2015) — - Sin embargo, se trata de una voluntad de contraculturalidad de muy baja intensidad conceptual que rara vez se manifiesta como ruptura o antagonismo explícito con los principios discursivos de la autoridad. Al contrario, los diversos casos aquí expuestos demuestran la continua búsqueda de legitimidad y de adscripción - isimulada? - a algunos de los discursos de autoridad vigente. El caso de Tamanique muestra cómo el desenganche de la tradición católica, al que parece decidida la comunidad en torno al hermano Lito, se está llevando a cabo mediante una cuidadosa aproximación a los símbolos y los principales requisitos de un discurso de autoridad emergente, el de las iglesias evangélicas y pentecostales. ${ }^{6}$ La misma estrategia parece ser subyacente al resto de las situaciones estudiadas.

Esta sofisticada estrategia cultural está enteramente sostenida por la oralidad. Eso explica, al menos en parte, las condiciones de posibilidad de su transmisión, así como su extraordinaria capacidad para la resignificación; su capacidad de responder a la urgencia del ahora sin renunciar al compromiso con la costumbre y el lugar. Pero también explica el continuo desafío lanzado al pensamiento científico y a su arsenal conceptual para designar de manera unívoca este complejo cultural. En ninguna otra ocasión se hace más evidente esta frustración que a la hora de hacer el trabajo de campo.

La oralidad une indisolublemente cuatro dimensiones: el momento, el lugar, el emisor y el receptor. El estudioso moderno se enfrenta al dilema de renunciar a su pretensión de control sobre el objeto de estudio que secularmente ejerce mediante la separación de estas cuatro dimensiones. Esta pérdida de control experimentada por el científico supone una importante renuncia a su propia autoridad, que está construida a partir de la promesa de la modernidad de dominar la realidad asumiendo la perfectibilidad de su relación con la razón, esto es, asumiendo la posibilidad de dotar de identidad a todo objeto exterior al sujeto. Los casos presentados aquí sobre las celebraciones del cumpleaños de san Simón no autorizan tan ambiciosa pretensión, es decir, "no ceden al ideal engañoso de la idea clara y distinta". 
Muchos aspectos del culto a san Simón se nos han escapado de entre los dedos, quedando arrumbados en pedazos de papel, no todos ellos suficientemente bien clasificados. Trozos de información que quizá, algún día, cobren nuevo sentido y puedan ser incorporados a una nueva perspectiva analítica. De momento nos conformamos con aportar un eslabón a la formación de una futura cadena de investigaciones que consiga llevar a la primera línea de los estudios culturales de la región esta asombrosa manifestación de religiosidad vernácula y a partir de ahí construir una plataforma de observación que constituya un avance real en nuestra comprensión de una de las sociedades más olvidadas por las ciencias sociales.

\section{Notas}

${ }^{1}$ La palabra "pueblo" la usamos entre comillas para referirnos a la expresión normalmente utilizada por los propios entrevistados para designarse a sí mismos en tanto parte de las clases sociales menos favorecidas.

2 Aquí, por ejemplo, presenciamos una sesión de espiritismo pública, ya al final de la noche, casi rayando el alba, en la que a través del hermano Lito y otros especialistas amigos suyos, como Julia Abarcas, de la que se hablará más adelante, se presentaron un buen número de hermanos y hermanas espirituales, como el propio Julio Cañas, Telesforo Sagastizado, Trema Adonay, Ernesto Interiano o Trinidad Huezo.

3 Zunil contiene un famoso templo a san Simón donde es probable que se produjera uno de los primeros episodios de la conversión del Maximón de Atitlán - a escasos kilómetros a vuelo de pájaro, que se convierten en interminables horas de mal viaje por carretera- La vecina Xela, a sólo nueve kilómetros, está rodeada de altares naturales dedicados a san Simón, y aquí es bastante explícita la influencia de las técnicas del espiritismo positivista, que en el Quetzaltenango de principios del siglo XIX tuvo uno de sus principales núcleos de recepción y difusión hacia toda Centroamérica (Valdés, 2010).

${ }^{4}$ Se utiliza un pseudónimo para proteger la identidad del informante.
${ }^{5}$ Aquí el caballo bien puede funcionar como símbolo de conquista y prestigio, al igual que la silla donde se sienta san Simón y que serviría también para canalizar la pretensión de justicia americana por excelencia, la de conciliar dos mundos enfrentados desde antiguo, según Alberto Vallejo Reyna (2015). Algo similar ocurre con la frecuente proximidad a Guadalupe y que claramente escora el culto a san Simón del lado de los sincretismos, hibridaciones y las secuencialidades identitarias (Taracena, 2008).

${ }^{6}$ En relación con este proceso de acercamiento del culto pseudocatólico a san Simón al universo de símbolos y leyes pentecostales y evangélicos en Guatemala, véase el artículo de Pédron Colombani (2008).

${ }^{7}$ La expresión la tomo de André De Muralt (2008: 100), en relación con la gnoseología aristotélica por oposición a la epistemología cartesiana.

\section{Referencias bibliográficas}

Bowman, Marion (2004). "Phenomenology, Fieldwork and Folk Religion". En Steven J. Sutcliffe (ed.), Religion: Empirical Studies. Aldershot: Ashgate.

Eliade, Mircea (1957). The Sacred and the Profane: The Nature of Religion. Nueva York: Harcourt.

Erquicia Cruz, Heriberto (2015). "El Hermano Macario Canizales de Izlaco". En A. García Espada (com.), Religiosidad popular salvadoreña. San Salvador: Dirección de Publicaciones e Impresos.

De Muralt, André (2008). La apuesta de la filosofía medieval. Madrid: Marcial Pons.

García Espada, Antonio (2015). "San Simón de Mesoamérica”. En A. García Espada (com.), Religiosidad popular salvadoreña. San Salvador: Dirección de Publicaciones e Impresos.

García Espada, Antonio (2013). "Religiosidad popular en Centroamérica. El desafío metodológico". En Teoríay Praxis, junio-diciembre, núm. 23, pp. 3-22.

García Espada, Antonio (1999). "Fray Odorico y el Karmapa. El Tibet de los viajeros medievales". En Medievalismo, vol. 9, núm. 9, pp. 83-103

González, José Manuel (2015). "Transcodificaciones y resignificaciones narrativas”. En A. García Espada 
(com.), Religiosidad popular salvadoreña. San Salvador: Dirección de Publicaciones e Impresos.

Huezo Mixco, Luis Roberto (2015). "Supervivencia y lucha en el universo mágico, periférico y pentecostal de San Salvador". En A. García Espada (com.), Religiosidad popular salvadoreña. San Salvador: Dirección de Publicaciones e Impresos.

Lemus, Jorge (2015). "La visión del inframundo en la tradición oral pipil”. En A. García Espada (com.), Religiosidad popular salvadoreña. San Salvador: Dirección de Publicaciones e Impresos.

León Florido, Francisco (2001). "Leer, copiar, pensar. Los orígenes medievales de la subjetividad". En Revista General de Información y Documentación, vol. 1l, núm. 2, pp. 93-115.

Lotman, Iuri (1996). La Semiosfera. Madrid: Cátedra.

Malinowski, Bronislaw ([1923]1995). "The Problem of Meaning in Primitive Languages". En C.K. Ogden e I.A. Richards (eds.), The Meaning of Meaning. Londres: Routledge.

Mendelson, Michael (1965). Los escándalos de Maximón. Guatemala: Tipografía Nacional.
Ong, Walter ([1982]2002). Orality and Literacy. The Technologizing of the Word. Nueva York: Routledge.

Pédron Colombani, Sylvie (2008). "Diversificación y competencia religiosa en Guatemala: entre pentecostalismo y cultos neotradicionales". En Sociedade e Estado, vol. 23, núm. 2, pp. 355-379.

Said, Edward (2008). Orientalismo. Barcelona: Mondadori. Sloek, Johannes (1996). Devotional Language. Berlín: De Gruyter.

Taracena Arriola, Arturo (2008). Guadalupanismo en Guatemala. Culto mariano y subalternidad étnica. México: UNAM.

Valdés, Roberto (2010). Masones, liberales y ultramontanos salvadoreños (1885-1886). Tesis de doctorado. Universidad Centroamericana José Simeón Cañas, El Salvador.

Vallejo Reyna, Alberto (2015). "El cabildo sagrado de los mayas. EL Justo Juez y Maximón en Chiapas y Guatemala: esbozos de una utopía". Ponencia presentada en el II Congreso de Religiosidades y Ritualidades en el Sur de México y Centroamérica, San Cristóbal de las Casas, octubre de 2015. 